\title{
Pengaruh Abu Vulkanik Kelud dan Pupuk Kandang terhadap Ketersediaan dan Serapan Kalium pada Jagung di Tanah Alfisol
}

\section{Effect of Kelud Volcanic Ash And Manure to The Availability and Corn Uptake of Potassium in The Alfisols}

\author{
Suntoro ${ }^{1)}$, Sudadi ${ }^{1)}$, Hery Widijanto ${ }^{1)}$, Galuh Novikah Widy Utami ${ }^{2)}$
}

\begin{abstract}
Kelud volcanic ash has high source of minerals, which is potassium. This study aims to determine the effect and find the best composition of Kelud volcanic ash and manure to the availability and corn uptake of potassium in the Alfisols. This research is expected to provide information on the composition of volcanic ash Kelud and proper manure for agriculture. This research was conducted in the greenhouse, in the Laboratory of Ecology and Management of Crop Production, and soil chemistry laboratory of the Faculty of Agriculture, Sebelas Maret University in June 2014 - January 2015. Research using completely randomized design which consists of two factors, there are the thickness of Kelud volcanic ash which consists of four levels A0 $(0 \mathrm{~cm}), A 1(2 \mathrm{~cm})$, A2 $(4$ $\mathrm{cm})$, and $\mathrm{A} 3(6 \mathrm{~cm})$ and the dose of manure were P0 $(0$ ton/ha), P1 $(2,5 \mathrm{ton} / \mathrm{ha})$, and P2 $(5$ ton/ha). Each combination treatment was repeated 3 times. The data were then analyzed using the $F$ test and continued with Duncan Multiple Range Test Test (DMRT) level of 95\%. The results showed that the interaction between the two treatments were no significant different. Availability Potassium gradually decreased with an increase in the dose of volcanic ash Kelud, allegedly because of the low value of the total potassium Kelud volcanic ash. The results of measurements of plant potassium uptake increased with increasing dose Kelud volcanic ash and manure.
\end{abstract}

Key words : Kelud volcanic ash, potassium, manure

\section{PENDAHULUAN}

Gunung Kelud merupakan salah satu gunung api di Indonesia. Aktivitas gunung ini terbilang cukup aktif. Erupsi Kelud berupa awan hitam dan abu vulkanik yang terakhir terjadi pada 13 Februari 2014. Abu vulkanik merupakan material vulkanik jatuhan yang disemburkan ke udara saat letusan. Abu vulkanik terdiri dari batuan berukuran besar sampai berukuran halus, yang berukuran besar biasanya jatuh disekitar sampai radius 5-7 km dari kawah, sedangkan yang berukuran halus dapat jatuh pada jarak mencapai ratusan hingga ribuan kilometer (Sudaryo dan Sucipto 2009). Dalam sehari, debu vulkanik Kelud menyebar hingga wilayah Jawa Barat. Karakteristik abu vulkanik Kelud yang cenderung halus, memiliki kemungkinan merusak tanaman atau perakaran lebih rendah.

Menurut Zuarida (1999), abu vulkanik Gunung Kelud Jawa Timur mengandung 45,9\% $\mathrm{SiO}_{2}$ dan mineral yang dominan adalah plagioklas intermedier. Abu vulkanik Gunung Kelud sendiri dapat meningkatkan $\mathrm{pH}$ tanah, meningkatkan tinggi tanaman, berat kering tanaman dan akar jagung. Sehingga, dapat dikatakan material vulkanik ini merupakan bahan yang kaya akan unsur hara. Namun, timbunan material vulkanik dalam jumlah banyak dapat menghambat pertumbuhan tanaman

\footnotetext{
${ }^{1)}$ Lecturer staff of Study Program of Agrotechnology, Faculty of Agriculture, Sebelas Maret University (UNS) in Surakarta.
}

${ }^{2)}$ Undergraduate Student of Study Program of Agrotechnology, Faculty of Agriculture, Sebelas Maret University (UNS) in Surakarta.

Contact Author: galuhnovikah.gn@gmail.com dan berdampak negatif pada tanah sebagai media tanamnya (Shoji dan Takahashi 2002).

Tindakan pemanfaatan abu vulkanik Kelud sebagai media tanam perlu dilakukan mengingat material ini mengandung unsur hara dalam jumlah yang besar, seperti Kalium. Kalium dalam tanaman berperan penting pada osmoregulasi, aktivasi enzim, dan pengaturan $\mathrm{pH}$ sel. Kalium juga mempunyai pengaruh yang mengimbangi akibat kelebihan nitrogen, hal ini menambah sintesa dan translokasi karbohidrat, dan mempercepat ketebalan dinding sel, dan kekuatan tangkai (Supardi dan Adiningsih 1986). Salah satu cara pemanfaatan abu vulkanik Kelud yang dapat dilakukan adalah dengan menambahkan media tanam lain seperti pupuk kandang dan tanah.

Pupuk kandang sebagai sumber Bahan Organik (BO) berfungsi untuk memperbaiki daya simpan air dan struktur media, dalam hal ini material vulkanik dan tanah, meningkatkan KTK dan daya ikat hara, serta sebagai sumber karbon, mineral, dan energi bagi mikroba. Ameliorasi dengan BO merupakan salah satu alternatif yang mampu meminimalisasi dampak negatif dari kandungan unsur kimia berlebih pada media.

\section{METODE PENELITIAN}

Penelitian dilakukan di rumah kaca, Laboratorium Ekologi dan Manajemen Produksi Tanaman (EMPT), Laboratorium Kimia Tanah dan Laboratorium Fisiologi Tumbuhan, Fakultas Pertanian Universitas Sebelas Maret Surakarta mulai bulan Juni 2014 sampai dengan bulan Januari 2015 .

Alat yang digunakan untuk penelitian mulai dari penanaman, panen, hingga analisis laboratorium yaitu

Pengaruh Abu Vulkanik Kelud dan Pupuk Kandang terhadap Ketersediaan 
polybag ukuran $45 \mathrm{~cm}$ x $45 \mathrm{~cm}$, cetok, timbangan analitik, meteran, dan alat laboratorium. Bahan-bahan yang digunakan dalam penelitian ini meliputi abu vulkanik Gunung Kelud, pupuk kandang, benih jagung, tanah Alfisol, dan kemikalia $\left(\mathrm{KCl} 1 \mathrm{~N}, \mathrm{~K}_{2} \mathrm{Cr}_{2} \mathrm{O}_{7}\right.$ $1 \mathrm{~N}, \mathrm{H}_{2} \mathrm{SO}_{4}$ pekat, $\mathrm{FeSO}_{4} 0,5 \mathrm{~N}, \mathrm{H}_{3} \mathrm{PO}_{4} 85 \%$, Alkohol $95 \%, \mathrm{NaOH} 30 \%, \mathrm{H}_{3} \mathrm{BO}_{3} 2 \%$, Amonium Asetat $1 \mathrm{~N}$, indikator DPA, indikator campuran, campuran garam Selenium, pengekstrak Bray I, Butir Zn, dan aquadest).

Penelitian ini menggunakan rancangan perlakuan faktorial yang disusun dengan menggunakan Rancangan Acak Lengkap (RAL) yang terdiri dari dua faktor perlakuan yaitu ketebalan abu vulkanik Kelud ketebalan $0 \mathrm{~cm}(\mathrm{~A} 0)$; ketebalan $2 \mathrm{~cm}(\mathrm{~A} 1)$; ketebalan $4 \mathrm{~cm}$ (A2); ketebalan $6 \mathrm{~cm}$ (A3), dan dosis pupuk kandang 0 ton ha ${ }^{-1}$ (P0); 2,5 ton ha ${ }^{-1}$; dan 5 ton ha ${ }^{-1}$. Masing-masing perlakuan diulang sebanyak 3 kali.

Pelaksanaan penelitian meliputi analisis awal media, persiapan media tanam, penanaman, pemeliharaan, pemanenan, dan analisis laboratorium. Pengamatan peubah utama meliputi kalium terlarut tanah dan serapan kalium jagung, ditunjang dengan sifat kimia tanah meliputi bahan organik tanah; kapasitas tukar kation; dan $\mathrm{pH}$ tanah serta pertumbuhan jagung meliputi tinggi tanaman; berat segar brangkasan; berat kering brangkasan; dan tingkat hijau daun (kadar klorofil). Analisis data dalam penelitian ini menggunakan uji $\mathrm{F}$ taraf kepercayaan $95 \%$, dan apabila perlakuan berpengaruh nyata dilanjutkan dengan uji jarak berganda Duncan taraf kepercayaan $95 \%$.

\section{HASIL DAN PEMBAHASAN}

\section{Karakteristik Tanah, Abu Vulkanik dan Pupuk Kandang Awal}

Hasil analisis tanah awal penting dilakukan untuk mengetahui karakteristik tanah yang digunakan dalam penelitian. Berdasarkan hasil analisis tanah awal menunjukkan bahwa Alfisols sebelum digunakan penelitian memiliki nilai bahan organic sangat rendah yaitu $0,18 \%$ dan $\mathrm{pH}$ agak masam yaitu 5,78 .

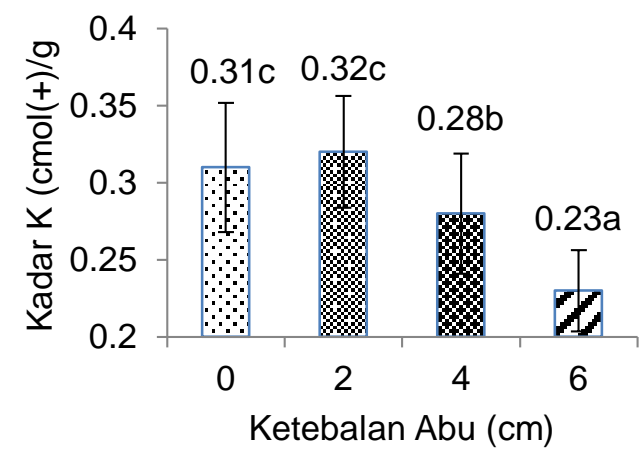

Kapasitas Tukar Kation (KTK) dari tanah Alfisol yaitu sedang $24,80 \mathrm{cmol}(+) / \mathrm{kg}$, sedangkan Kalium tertukar tanah Alfisol sedang yaitu 0,49 me/100g. Hasil analisis tersebut sesuai dengan pernyataan Munir (1992) bahwa pada umumnya tanah alfisol memiliki kandungan bahan organik dari sedang hingga rendah, $\mathrm{pH}$ tanah yang agak masam hingga netral, dan kapasitas tukar kation yang rendah hingga tinggi. Menurut Minardi (2002) tanah alfisol mempunyai K tersedia yang sedang sampai tinggi, $\mathrm{N}$ total rendah, dan $P$ tersedia sangat rendah. Secara kimiawi tanah alfisol memiliki kesuburan tanah yang rendah. Masukan hara yang tinggi dari pupuk organik maupun anorganik serta dari abu vulkanik dibutuhkan untuk meningkatkan hara tanah alfisol dan mempertahankan pertumbuhan tanaman yang optimal.

Letusan Gunung Kelud 2014 lalu mengeluarkan limpahan vulkanik yang tersebar tidak hanya di sekitar Gunung Kelud, namun juga di beberapa wilayah Jawa. Karakteristik Abu Vulkanik Kelud juga penting diketahui sebelum dilakukannya penelitian. Abu vulkanik Kelud memiliki $\mathrm{pH}$ cenderung netral yaitu 6,58 dan Kalium total abu sebesar 1,03 me/100g atau $0,04 \%$. Berdasarkan hasil analisis dapat diketahui bahwa kandungan hara cenderung rendah karena material vulkanik merupakan bahan baru (recent material) yang relatif belum dapat menyumbangkan unsur hara bagi tanaman karena belum mengalami pelapukan yang sempurna.

Pupuk kandang banyak digunakan dalam kegiatan pertanian karena dapat menyediakan unsur hara yang diperlukan tanaman. Menurut Rosmarkam dan Yuwono (2002), pupuk kandang relatif lebih kaya hara dan mikroba daripada limbah pertanian. Pernyataan tersebut sesuai dengan hasil analisis yang menunjukkan nilai $\mathrm{K}$ total pupuk kandang sebesar $1,07 \%$ lebih besar dari abu vulkanik Kelud.

\section{K tertukar tanah}

Berdasarkan uji $F$ taraf kepercayaan 95\%, diketahui bahwa aplikasi ketebalan abu vulkanik Kelud dan takaran pupuk kandang memberikan pengaruh sangat nyata $(p<0,01)$ terhadap $\mathrm{K}$ tertukar dalam tanah, akan tetapi keduanya tidak saling berinteraksi.

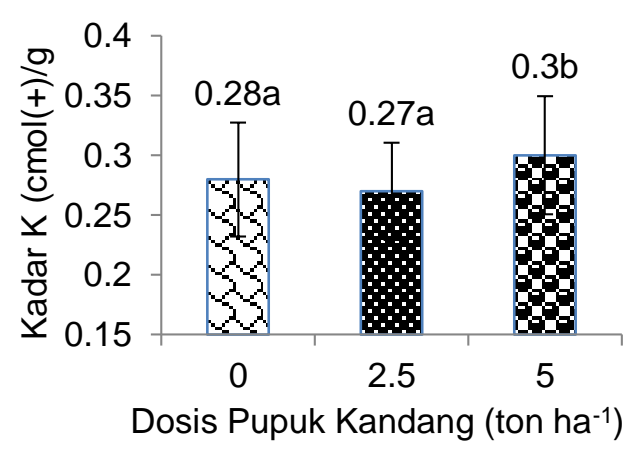

Keterangan: Angka yang diikuti dengan huruf yang sama pada item yang sama menunjukkan berbeda tidak nyata pada uji DMRT taraf $95 \%$

Gambar 1. Pengaruh ketebalan abu vulkanik Kelud dan takaran pupuk kandang terhadap $\mathrm{K}$ tertukar tanah alfisol 
Abu vulkanik Kelud merupakan bahan baru berukuran kecil yang belum melapuk sempurna sehingga belum banyak memiliki muatan negatif yang dapat menjerap hara Kalium. Gambar 1 menunjukkan bahwa semakin tebal abu vulkanik Kelud yang ditambahkan maka $\mathrm{K}$ tertukar menurun. $\mathrm{Hal}$ ini dikarenakan penambahan abu vulkanik Kelud dalam satuan berat tanah yang sama dapat menurunkan persentase muatan negatif tanah sebelumnya, sehingga nilai Kalium yang tertukar akan menurun. Gambar 1 juga menjelaskan bahwa penambahan dosis pupuk kandang cenderung meningkatkan Kalium tertukar tanah. Pupuk kandang memiliki daya ikat ion yang tinggi, sehingga meningkatkan aktivitas penjerapan Kalium.

\section{Serapan $\mathrm{K}$ jagung}

Berdasarkan uji $F$ taraf kepercayaan 95\%, diketahui bahwa aplikasi ketebalan abu vulkanik Kelud dan takaran pupuk kandang tidak saling berinteraksi, namun memberikan pengaruh sangat nyata $(p<0,01)$ terhadap serapan $\mathrm{K}$ jagung.

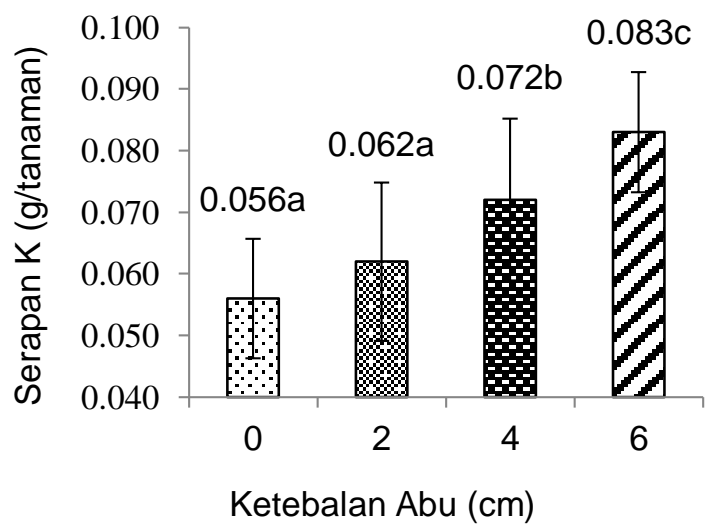

Berdasarkan gambar 2. dapat diketahui bahwa serapan $\mathrm{K}$ tertinggi terjadi pada perlakuan ketebalan abu vulkanik Kelud $6 \mathrm{~cm}$ dan takaran pupuk kandang 5 ton ha ${ }^{-1}$. Diduga serapan Kalium meningkat akibat adanya pengaruh dari pertumbuhan jagung. Tanah Alfisol memiliki tekstur yang dominan lempung dengan porositas yang rendah, selain itu strukturnya padat sehingga sulit ditembus akar. Penambahan abu vulkanik Kelud dapat meningkatkan porositas tanah Alfisol. Semakin banyak abu vulkanik Kelud yang ditambahkan maka pori mikro semakin porus, sehingga pertumbuhan akar akan meningkat. Akar yang menembus tanah kemudian menyerap Kalium dalam bentuk $\mathrm{K}^{+}$dan ditranslokasikan dari jaringan tua menuju bagian-bagian yang lebih muda (Tisdale et al. 1985). Kalium berperan sebagai pengatur proses fisiologi tanaman, pembentukan protein, mengatur distribusi air dalam jaringan sel, memperbesar batang sehingga dapat meningkatkan berat segar dan berat kering tanaman.

Keterangan : Angka yang diikuti dengan huruf yang sama pada item yang sama menunjukkan berbeda tidak nyata pada uji DMRT taraf $95 \%$.

Gambar 2. Pengaruh ketebalan abu vulkanik Kelud dan takaran pupuk kandang terhadap serapan K jagung

\section{Tinggi tanaman}

Berdasarkan uji $F$ taraf kepercayaan 95\%, diketahui bahwa aplikasi ketebalan abu vulkanik Kelud dan takaran pupuk kandang tidak saling berinteraksi dan penambahan dosis pupuk kandang memberikan pengaruh nyata $(p<0,05)$ terhadap serapan tinggi jagung. Berdasarkan uji $F$ taraf kepercayaan $95 \%$ perlakuan takaran pupuk kandang memberikan pengaruh nyata $(p<0,05)$ terhadap tinggi tanaman jagung. Pertumbuhan jagung sangat dipengaruhi oleh ketersediaan unsur hara terutama unsur hara makro. Menurut Soepardi (1983), pupuk kandang merupakan sumber hara makro yang memberikan pengaruh paling cepat dan menyolok pada pertumbuhan tanaman, serta dapat meningkatkan jumlah hara tersedia dan menaikkan hasil tanaman, serta dapat mempertahankan bahan organik tanah. Pupuk kandang juga mengandung sejumlah unsur hara makro yang dibutuhkan oleh tanaman. Kandungan unsur hara yang terdapat pada pupuk kandang dan tanah akan ditranslokasikan pada bagian-bagian vegetatif tanaman, sehingga mempengaruhi pertumbuhan vegetatif tanaman seperti tinggi tanaman.

\section{KESIMPULAN DAN SARAN}

\section{Kesimpulan}

Berdasarkan hasil penelitian, kesimpulan yang dapat diambil untuk menjawab tujuan dan masalah penelitian adalah sebagai berikut :

1. Interaksi antara abu vulkanik Kelud dan pupuk kandang tidak berpengaruh nyata terhadap semua aspek yang diuji.

2. Nilai Kalium tertukar terendah terjadi pada perlakuan ketebalan abu vulkanik Kelud $6 \mathrm{~cm}$ yaitu $0,23 \mathrm{cmol}(+) / g r a m$, sedangkan penambahan dosis 


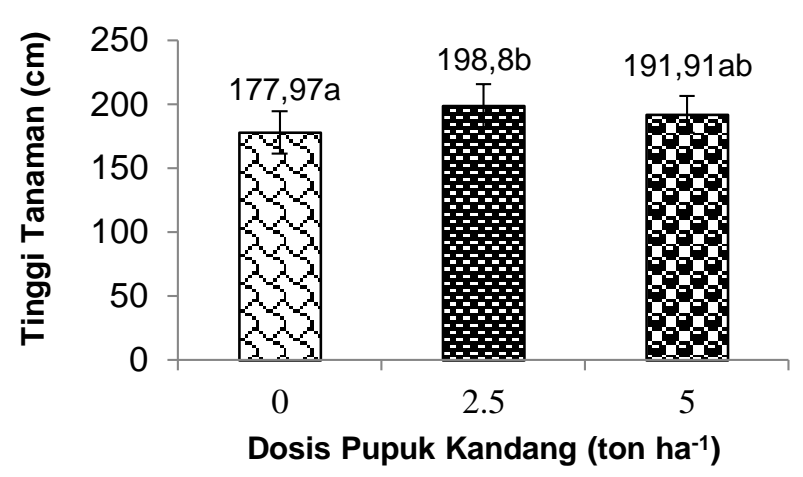

Keterangan: Angka yang diikuti dengan huruf yang sama pada item yang sama menunjukkan berbeda tidak nyata pada uji DMRT taraf $95 \%$.

Gambar 3. Pengaruh takaran pupuk kandang terhadap tinggi tanaman jagung

pupuk kandang 5 ton ha $^{-1}$ menghasilkan Kalium tertukar tertinggi yaitu $0,3 \mathrm{cmol}(+) / g r a m$.

3. Penambahan abu vulkanik Kelud pada media tanam berpengaruh sangat nyata terhadap $\mathrm{K}$ tertukar dalam tanah yaitu semakin tebal abu vulkanik Kelud maka $\mathrm{K}$ tertukar tanah akan semakin rendah, hal ini dikarenakan abu vulkanik Kelud belum melapuk sempurna sehingga belum banyak memiliki muatan negatif yang dapat menjerap hara Kalium.

4. Perlakuan penambahan abu vulkanik Kelud $6 \mathrm{~cm}$ menghasilkan serapan Kalium tertinggi yaitu 0,083 gram/tanaman, sedangkan nilai serapan Kalium tertinggi pada penambahan pupuk kandang terjadi pada dosis 5 ton ha ${ }^{-1}$ yaitu 0,074 gram/tanaman.

5. Serapan Kalium meningkat dengan penambahan abu vulkanik Kelud, hal ini abu vulkanik Kelud meningkatkan porositas tanah sehingga meningkatkan pertumbuhan akar untuk menyerap Kalium.

\section{Saran}

Berdasarkan penelitian ini, perlu adanya penelitian lanjutan untuk mengetahui kombinasi takaran pupuk kandang dan tebal abu vulkanik terhadap ketersediaan dan serapan hara serta produktivitas tanaman setelah melalui proses dekomposisi, sehingga dapat menjadi rekomendasi bagi petani.

\section{DAFTAR PUSTAKA}

Minardi S. 2002. Kajian komposisi pupuk NPK terhadap hasil beberapa varietas tanaman buncis tegak di tanah alfisol. Sains Tanah 2(1).

Rosmarkam A, Yuwono NW. 2002. Ilmu kesuburan tanah. Yogyakarta (ID): Kanisius.

Shoji S, Takahashi. 2002. Environmental and agricultural significance of volcanic ash soils. J Soil Sci Plant Nutr 73: 113-135.

Soepardi G. 1983. Sifat dan ciri tanah. Bogor (ID): Departemen IImu Tanah Fakultas Pertanian IPB.

Sudaryo, Sucipto. 2009. Identifikasi dan penentuan logam berat pada tanah vulkanik di daerah cangkringan, Kabupaten Sleman dengan metode analisis aktivasi neutron cepat. Yogyakarta. Seminar Nasional V SDM Teknologi 5 November 2009.

Supardi S, Sri AJ. 1982. Korelasi antara kalium terestrak dengan bahan kering dan kalium diserap tanaman. Prosiding pertemuan teknis penelitian tanah. Cipayung 13-15 Desember 1982. Badan Penelitian dan Pengembangan Pertanian. Departemen Pertanian.

Tisdale SL, Nelson WL, Beaton JD. 1985. Soil fertility and fertilizer. New York (NY): Macmillan Publishing Company.

Zuraida. 1999. Penggunaan abu volkan sebagai amelioran pada tanah gambut dan pengaruhnya terhadap sifat kimia tanah dan pertumbuhan jagung. Thesis. Bogor. Program Pascasarjana Institut Pertanian Bogor. 